УДК 37.032

https://doi.org/10.33296/2707-0255-11(21)-13

SUKHOVERKHOVA OLENA

Postgraduate Student of the $2^{\text {nd year }}$

at the Department of the pedagogy, methodology and management of the education

Ukrainian Engineering Pedagogical

Academy

Kharkiv, Ukraine

https://orcid.org/0000-0001-9579-2976

\title{
PROJECT ACTIVITIES IN THE CONTEXT OF DONALD SUPER'S CONCEPT OF CAREER DEVELOPMENT
}

\begin{abstract}
The article highlights the need to include project activities as an important component of the learning process. The purpose of project activities is to provide the necessary foundation for individuals to work on their own development and to provide the necessary aids to support the desire to grow and improve. It is suggested that Donald Super's ideas should be taken into account when planning the stages of project activities, adding a stage for individual reflection throughout the project. The development of the child is a key task for the school, the issues of giving importance to the project activities in the curriculum are defined. The idea of using project activities as an environment for mastering competencies is put forward. A point of view on the value of mastering competencies and skills during schooling that will help be effective in the future is provided, for the purposes of our age period according to Donald Super. A viewpoint on the need for student participation in project activities in order to activate the personal qualities of participants in the learning process is outlined. Learning activities in institutions of general secondary education should be aimed at the development of the personality of education applicants. Opportunities to try themselves in "different roles as a performer" are provided exactly by the project method of learning, which corresponds to the age stage of professional development according to Donald Super. The level of conscious acquisition of knowledge and skills when working on a project or case study increases significantly and is added to the process of shaping one's career trajectory. The introduction of this type of activity in the practice of the educational institution solves a wide range of problems faced by institutions of general secondary education in the process of its functioning.
\end{abstract} theory.

Key words: self-determination, project activity, learning, Donald Super's

(c) Українська інженерно-педагогічна академія

(C) ГО «Школа адаптивного управління соціально-педагогічними системами»

(C) Суховерхова О. 
Introduction. It is generally accepted that the development of self-concept of secondary education recipients must be provided at schools. It can be done in different ways. We briefly outline the possible positive impact of project activities on the development and formation of self-concept of secondary education recipients in the context of Donald Super's concept of career development. Donald Super believed that clients' opportunities (client is the one who is in the search for the career) always develop in accordance with the development of age stages. He distinguished five stages of career development, which in turn was a detailing of the work done before him. The first stage is from birth to 14 years. This is the period in which the imagination develops, skills are formed and knowledge about the professions is acquired. This stage is called the growth. In the second stage, which Super suggests, the individual develops his or her imagination and abilities, finds their own ideas about professions. In the second stage the person tries out in different kinds of occupations and already estimates the possibilities and abilities of their application. The main task of this stage is to investigate the world of professions and to specify the further plan of career development (in the age framework is the period from 15 to 24 years old). These are the two stages or the periods that we are most interested in our situation. As the subsequent stages from the age perspective are from 25 years and above so it is about the growth and development of the adult person and we are not talking about it here.

The relevance of this article lies in the fact that as rule project activities are perceived separately from the process of the personal development and the formation of ideas connected with the career guidance. The ability to navigate the opportunities offered by a higher education institution while taking into account your skills and abilities is always a challenge to obtain. On the one hand, vocational guidance work at schools is carried out in the usual way, on the other hand, the development and rapid change of our society leaves school leavers a difficult situation to solve.

\section{Analysis of recent research and publications}


Formulating goals of the article. The purpose of this article is to determine the importance of incorporating project activities into the secondary school curriculum, introducing and regularly using a self-reflection unit and developing selfreflection and self-regulation skills. Using Donald Super's theory as a starting point can give the process of project activities more influence on career guidance activities in school.

Statement of the main material. A critical part of education is also the development of students' ability to interact and work with others-from the teachers who guide them and ignite their interests and passions to their peers with whom they work, learn, and teach. Learning is ultimately a social experience because it shapes people into more mature social actors capable of participating in civil society and leading productive lives. But project learning is a powerful force in making these experiences more effective and efficient. In addition, this type of learning can accelerate our knowledge of which training experiences work best for which students, in which circumstantial, so that educators can adapt to the reality that they can help all children find their Interests and reach their full potential. Thus, we see the positive aspects of the use of project activities for the development of personal skills[4].

Based on Super's theory, graduate students and beyond should be involved in project activities that develop a positive personal self-image and career concept for themselves. Donald Super calls the tasks related to this stage simply crystallization[3].

The task of crystallization begins with the formation of the necessary plan of activities in which students should be involved in the development of project work they may use a variety of skills and they will be useful in the future just for each student and personally. Thus, participants of project activities simultaneously learn and receive and perform tasks related to the development of career activities. Students can acquire the necessary skills in the process of learning the types of skills listed below. 
We define such necessary experiences and skills which are used during the project work: enhancing self-efficacy, promoting a harmonious classroom culture, instructional design basics, Using best working practices, allowing differentiated instruction at the classroom and student level, being accessible to students with learning differences and Special Needs Learning Objective, supporting socialemotional learning, incorporating 21 st century skills, meeting discipline-specific standards in the local context, Easy to implement.

Students are better able to serve with well-developed tasks that help them explore careers and own abilities that align with their interests. Through project work, students learn to develop a sustainable and positive self-concept based on a career plan that includes exploration of their own lives, careers, relationships, and options after graduation. In addition, having a feedback stage as an integral part of the project means that students will be served more effectively and integrated over time. The advantage of this or any well-structured program is that students become active participants in planning for their future[3].

A rewarding career doesn't usually happen by accident, it is planned, watched, worked on, and executed. Careers are developed through the motivations, aspirations, and goals that students set. While educators can never perfectly execute career development for every student in our neighborhoods, they should not be afraid to have a template plan for project activities built on the recognition of students' developmental levels and professional goals. At the end of the school year, teacher professionals rejoice in knowing that students can proudly formulate their plan based on well-chosen best practices of focused inquiry and meaningful activities and tasks[2].

The importance of the work process cannot be disputed by anyone So it is that everyone faces the difficulty of finding the right occupation for themselves Our work contains personal characteristics, shows who we are, marks our personality, our habits and our way of life. 
Conclusion. Directions for further investigation. This paper has underlined the importance of the process of introducing students to participating in project activities, including an analysis of what has been done, an awareness of what has been learned during the work and how it can be applied in the future. Having found the career that suits us we can live our life enjoying the process of work but not finding the necessary job very often leads to dissatisfaction with life depression. Finding a career is not just a process we spend a little time for. But this process of finding a career path is really difficult for school students who do not have the skills to understand what their future career should be like. Making a decision about future career is a very complicated process and in this case school and society can help. Even if we just offer to participate in project activities and give an understanding of the things a student can do, this can help with self-determination. Directions for future research are to identify activities to find out the level of influence of participation in project activities on the self-determination of students and to develop questionnaires for feedback following the project period.

\section{REFERENCES}

1. Brewer A.M. Encountering, Experiencing and Shaping Careers: Thinking About Careers in the21st Century : Springer, 2018

2. Savickas M. Career Adapt-Abilities Scale: Construction, reliability, and measurement equivalence across 13 countries / M. Savickas, E. Porfeli. //Journal of Career Assessment. - 2012. - №80(3). - C. 661-673 In D.

3. Super, D. E. (1990). A life-span, life-space approach to career development.

Brown \& L. Brooks (Eds.), Career choice and development: Applying contemporary theories to practice (2nd ed., pp. 197-261). San Francisco:Jossey-Bass.

4. The future of work in Europe Automation, workforce transitions, and the shifting geography of employment. Discussion paper June 2020 Authors: Sven Smit, Amsterdam; Tilman Tacke, Munich; Susan Lund, Washington, DC; James Manyika, San Francisco; Lea Thiel, Munich [Електронний ресурс]. / Режим доступу: https://www.mckinsey.com/ /media/McKinsey/Featured\%20Insights/Future\%20of\% 20Organizations/The\%20future\%20 of \%20work\%20in\%20Europe/MGI-The-futureof-work-in-Europe-discussion-paper.pdf 


\title{
СУХОВЕРХОВА ОЛЕНА
}

здобувачка

ступеня

ДОКТОРА

ФІЛОСОФІЇ другого року навчання

кафедри педагогіки, методики та менеджменту освіти Української інженерно-педагогічної академії, м. Харків, Україна

\section{ПРОЄКТНА ДІЯЛЬНІСТЬ В КОНТЕКСТІ ТЕОРІЇ ПРОФЕСІЙНОГО РОЗВИТКУ ДОНАЛДА СЬЮПЕРА}

\begin{abstract}
Анотація Стаття висвітлює необхідність вживання проєктної діяльності, як важливої складової навчального процесу. Метою проєктної діяльності $\epsilon$ подання необхідної основи особистості для роботи над власним розвитком та забезпечення необхідними допоміжними засобами для підтримки бажання зростати та вдосконалюватись. Висловлюється думка, щодо врахування ідей Доналда Сьюпера під час планування єтапів проєктної діяльності, додавання єтапу індивідуальної рефлексії в перебіг проєкту. Розвиток дитини є ключовим завданням для школи, визначається питання вагомості додання проєктної діяльності в програму навчання. Висувається ідея використання проєктної діяльності як осередка для опанування компетенцій. Надано точку зору про цінність освоєння учнівством під час навчання в навчальному закладі компетенцій та вмінь, які допоможуть бути ефективними в майбутньому відповідно до мети нашого вікового періода за Доналдом Сьюпером. Викладена точку зору щодо необхідності участі школярства в проєктній діяльності 3 метою активізації особистих якостей учасників навчального процесу. Навчальна діяльність в закладах загальної середньої освіти повинна бути скерованою на розвиток особистості здобувачів освіти. Можливості спробувати себе в «різноманітних ролях виконавцем» надає саме проєктний метод навчання, що відповідає віковому єтапу професійного розвитку за Доналдом Сьюпером. Рівень усвідомленого отримання знань та умінь під час роботи над проєктом або кейсом значно зростає та додається процес будування своєї карьєрної траєкторії. Впровадження цього виду діяльності в практику навчального закладу вирішує широке коло задач, що стоять перед установами загальної середньої освіти в процесі свого функціонування.

Ключові слова: самовизначення, проєктна діяльність, навчання, теорія Доналда Сьюпера.
\end{abstract}

(C) Українська інженерно-педагогічна академія

(c) ГО «Школа адаптивного управління соціально-педагогічними системами»

(C) Суховерхова О. 
Електронне наукове фахове видання «Адаптивне управління: теорія і практика.

\title{
СУХОВЕРХОВА ЕЛЕНА
}

аспирантка второго года обучения кафедры педагогики, методики и менеджмента образования Украинской инженерно-педагогической академии, г. Харьков

\section{ПРОЕКТНАЯ ДЕЯТЕЛЬНОСТЬ В КОНТЕКСТЕ ТЕОРИИ ПРОФЕССИОНАЛЬНОГО РАЗВИТИЯ ДОНАЛДА СЬЮПЕРА}

\begin{abstract}
Аннотация Статья освещает проблему необходимости включения проектной деятельности как важной составляющей учебного процесса. Целью проектной деятельности является предоставление необходимой основы личности для работы над собственным развитием и обеспечение необходимыми вспомогательными средствами для поддержки стремления расти и совершенствоваться. Высказывается мнение, относительно учета идей Доналда Сьюпера при планировании этапов проектной деятельности, добавление этапа индивидуальной рефлексии на протяжении проекта. Развитие ребенка является ключевой задачей для школы, определяются вопросы придания важности проектной деятельности при включении в программу обучения. Выдвигается идея использования проектной деятельности как среды для освоения компетенций. Предоставлено точку зрения о ценности освоения ученичеством во время обучения в учебном заведении компетенций и умений, которые помогут быть эффективными в будущем, в целях нашего возрастного периода по Дональду Сьюперу. Изложена точка зрения о необходимости участия ученичества в проектной деятельности с целью активизации личных качеств участников учебного процесса. Учебная деятельность в учреждениях общего среднего образования должна быть направленной на развитие личности соискателей образования. Возможности попробовать себя в «различных ролях исполнителем» предоставляет именно проектных метод обучения, что соответствует возрастному этапу профессионального развития по Дональду Сьюперу. Уровень осознанного получения знаний и умений при работе над проектом или кейсом значительно возрастает и добавляется в процесс формирования своей карьерной траектории. Внедрение этого вида деятельности в практику учебного заведения решает широкий круг задач, стоящих перед учреждениями общего среднего образования в процессе своего функционирования.

Ключевые слова: самоопределение, проектная деятельность, обучение, теория Дональда Сьюпера.
\end{abstract}

\footnotetext{
(C) Українська інженерно-педагогічна академія

(C) ГО «Школа адаптивного управління соціально-педагогічними системами»

(C) Суховерхова О.
} 